\title{
Study to Assess the Knowledge, Attitude and Practices of Blood Donation among Students of Gandhi Medical College and TIT Engineering Colleze, Bhopal, Madhya Pradesh, India
}

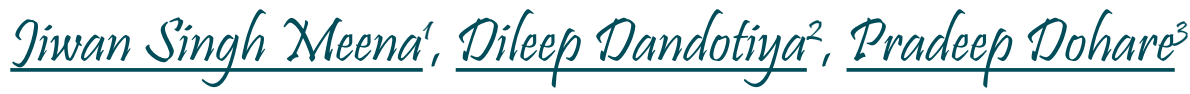

${ }^{1}$ Associate Professor, ${ }^{2,3}$ Post Graduate Resident, Department of Community Medicine, Gandhi Medical College, Bhopal, Madhya Pradesh.

DOI: https://doi.org/10.24321/2455.7048.201815

\section{Abstract}

Background: The WHO theme for World Blood Donor Day 2011 was "More blood More life". This theme reinforced the urgent need for more people all over the world to become life-savers by volunteering to donate blood regularly. Blood can save millions of lives. The requirement of blood and blood products in a country depends on the population, health care structure, prevalence of conditions requiring regular transfusions, such as hemophilia and thalassemia etc.

Aim: To assess and improve the knowledge attitude and practice of blood donation among undergraduate college students of GMC \& TIT Engineering College Bhopal.

Materials and Methods: This cross-sectional study was conducted for a period of 6 months from July 2017 to December 2017 among 500 college students of GMC \& TIT Engineering College, Bhopal, Madhya Pradesh, India using convenience sampling, where blood donation camps were to be held. Data was collected through self-administered questionnaires and analyzed by Epi info-7 software.

Results: The overall knowledge on blood donation among total respondents was increased from $28.9 \%$ to $52.6 \%$. In our sample size of 500 after making them aware regarding blood donation and its benefits 193 respondents gave consent and showed positive attitude towards donation. Most common reason for donating blood was a sense of social responsibility and most common reason of non-donation was fear of the procedure. An $85 \%$ of the students were of the view that they would donate blood if asked. Students suggested that small incentives like certificates and arranging transport for blood donation would make it easier to donate.

Conclusion: After assessment of all 500 individuals we came to the conclusion that awareness and knowledge among students and individuals was increased from $28.9 \%$ to $52.7 \%$. And after encouraging all individuals for donation and keeping a target of 100 unit's collection, we were able to collect 193 units in the course of our project.

Keywords: Blood donation, GMC, TIT, Undergraduate students

Corresponding Author: Dr. Pradeep Dohare, Department of Community Medicine, Gandhi Medical College, Bhopal, Madhya Pradesh. E-mail Id: pkdohare424@gmail.com

Orcid Id: https://orcid.org/0000-0001-7568-9007

How to cite this article: Meena JS, Dandotiya D, Dohare P. Study to Assess the Knowledge, Attitude and Practices of Blood Donation among Students of Gandhi Medical College and TIT Engineering College, Bhopal, Madhya Pradesh, India. Epidem Int 2018; 3(3): 28-31. 


\section{Introduction}

In adults, there is approximately 4.5-6 quarts of blood. This essential fluid carries out the critical functions of transporting oxygen and nutri ents to our cells and getting rid of carbon dioxide, ammonia, and other waste products. In addition, it plays a vital role in our immune system and in maintaining a relatively constant body temperature. Blood is a highly specialized tissue composed of more than 4,000 different kinds of components. Four of the most important ones are red cells, white cells, platelets, and plasma ${ }^{1}$.

All humans produce these blood components--there are no populational or regional differences. The factors impacting blood donation decision are varied and complex. The prediction of blood donation behaviour can be determined by intention to donate, which in turn is affected by positive or negative attitude, subjective factors like social pressure and perceived ease or difficulty in performing the blood donation. ${ }^{2,3}$ According to the World Health Organization (WHO), $1 \%$ of the population is generally the minimum needed to meet the country's most basic requirements for blood; hence the estimated blood requirement of South East Asia is about 18 million units per year, and the annual collection is about 9.4 million units, leaving a gap of 6 million units. ${ }^{4-6}$ In India, the proportion of blood units collected through voluntary blood donation at National AIDS Control Organization (NACO) supported blood banks was $84.3 \%$ in $2012 .^{7}$ There is a need to fill this gap of demand and supply from various sources.

\section{Objectives}

General Objective: To assess and improve the knowledge attitude and practice of blood donation among undergraduate college students of GMC \& TIT Engineering College Bhopal.

Specific Objective: To measure the level of knowledge regarding blood donation and its importance, to find out negative and positive attitudes towards blood donation and to encourage students to donate minimum 100 unit of blood.

\section{Methodology}

This cross sectional study was conducted for a duration of 6 months from July 2017 to December 2017 among under graduate medical students in Gandhi Medical College and TIT Engineering College, Bhopal, M.P. After obtaining Institutional Ethical clearance and permission from concerned College this study was executed. Five hundred students were participated on voluntary basis. The nature and purpose of study was explained in brief to the participants and assured confidentiality in collection of personal data. A well-structured validated and pre-tested questionnaire on knowledge, attitude and practice on blood donation was assessed among students through questions covering nature of donation, requirements for donation; test carried in the blood banks, storage, blood components, usage of blood and health benefits for blood donors. A scoring mechanism was used to understand knowledge level and attitude on blood donation; each correct answer was given one score and in practice reason for not a regular donor was assessed and results were expressed in percentage.

Data was entered in MS Excel and analysed using Epi Info 7 Software.

\section{Results}

Demographic Characters: The study included 500 both medical \& engineering college students.

Table 1.Knowledge and awareness about blood donation

\begin{tabular}{|c|c|c|}
\hline Knowledge & $\begin{array}{c}\text { Pre- } \\
\text { intervention }\end{array}$ & $\begin{array}{l}\text { Post- } \\
\text { intervention }\end{array}$ \\
\hline $\begin{array}{l}\text { Awareness of blood } \\
\text { shortage in Bhopal }\end{array}$ & $37.7 \%$ & $65.8 \%$ \\
\hline $\begin{array}{l}\text { Suitable age for blood } \\
\text { donation }\end{array}$ & $32.5 \%$ & $65.8 \%$ \\
\hline $\begin{array}{l}\text { Minimum weight for } \\
\text { blood donation }\end{array}$ & $28 \%$ & $54.4 \%$ \\
\hline $\begin{array}{l}\text { Minimum hemoglobin } \\
\text { needed for donation }\end{array}$ & $38.6 \%$ & $53.8 \%$ \\
\hline $\begin{array}{l}\text { Tests performed on } \\
\text { donated blood }\end{array}$ & $25.7 \%$ & $62.1 \%$ \\
\hline $\begin{array}{l}\text { Time between } \\
\text { two consecutive } \\
\text { donations }\end{array}$ & $39.3 \%$ & $55.4 \%$ \\
\hline $\begin{array}{c}\text { Blood volume donated } \\
\text { per donation }\end{array}$ & $33 \%$ & $60.6 \%$ \\
\hline $\begin{array}{c}\text { Number of lives saved } \\
\text { from each unit }\end{array}$ & $21.5 \%$ & $33.7 \%$ \\
\hline $\begin{array}{c}\text { Benefits of blood } \\
\text { donation to donors }\end{array}$ & $18.4 \%$ & $49.7 \%$ \\
\hline $\begin{array}{l}\text { Knowledge about } \\
\text { universal donors }\end{array}$ & $20.1 \%$ & $44.0 \%$ \\
\hline $\begin{array}{l}\text { Knowledge about } \\
\text { commonest blood } \\
\text { group }\end{array}$ & $22.8 \%$ & $34.0 \%$ \\
\hline $\begin{array}{l}\text { Overall percentage of } \\
\text { knowledge }\end{array}$ & $28.9 \%$ & $52.6 \%$ \\
\hline
\end{tabular}

Table 1 shows that the overall knowledge on blood donation among 500 respondents. It was observed that the basic knowledge pertaining to blood donation was increased from $28.9 \%$ during pre intervention phase to $52.6 \%$ in post intervention phase. 
Table 2.Attitude and practice

\begin{tabular}{|c|c|c|c|}
\hline $\begin{array}{c}\text { S. } \\
\text { No. }\end{array}$ & Attitude and Practice & Frequency & Percentage \\
\hline \multicolumn{3}{|c|}{ Source of information regarding blood donation } \\
\hline 1. & Television & 207 & 41.4 \\
\hline 2. & Internet & 188 & 37.6 \\
\hline 3. & Newspaper & 105 & 21 \\
\hline \multicolumn{4}{|c|}{ Reasons for not donating blood } \\
\hline 1. & Don't think of it & 150 & 30.0 \\
\hline 2. & Lack of opportunity & 238 & 47.6 \\
\hline 3. & $\begin{array}{c}\text { Fear of pain, } \\
\text { weakness and anemia }\end{array}$ & 111 & 22.2 \\
\hline 4. & No one ever asked to \\
& 1 & 0.2 \\
\hline
\end{tabular}

Table 2 shows that the source of information regarding blood donation was taken from television (41.4\%) followed by through internet (37.6\%) and $21 \%$ by newspaper. Reason for not donating blood was lack of opportunity (47.5\%), don't think of it (30.0\%), fear of pain, weakness and anemia (22.2\%) and $0.2 \%$ were said that no one ever asked to donate.

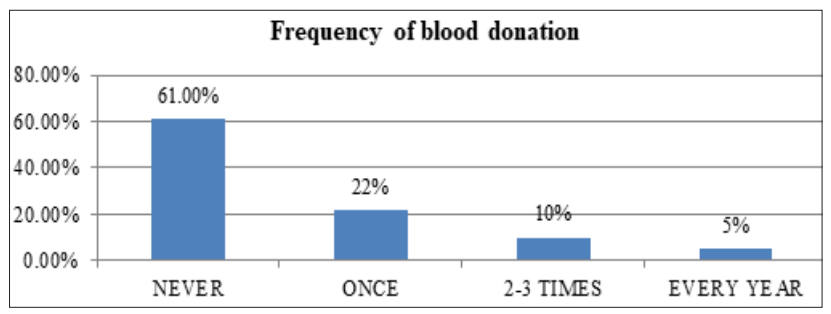

Figure 1.Frequency of blood donation among the respondents

Figure 1 shows that maximum students (61.0\%) did not donate the blood, $22 \%$ did only one-time blood donation, $10 \%$ did the $2-3$ times blood donation and the rest $5 \%$ did blood donation in a every year.

\section{Discussion}

Studies to understand the various factors that could change the perception and awareness about blood donation among the student community may come out to be useful for the successful implementation of $100 \%$ VBD program in the Bhopal city. The present study assessed the knowledge, attitudes and practice regarding blood donations and transfusion services among the undergraduate students of GMC \& TIT engineering college Bhopal (M.P.). Knowledge on blood donation among students was measured using the following questions; which comprised of respondents' understanding on benefits of blood donation to donors; the general requirements to become an eligible donor, how many times in a year a healthy male and female can donate blood, volume of donated blood, number of days donated blood can be stored; components of donated blood; maximum number of lives saved from the donated blood. The overall knowledge on blood donation after postintervention among the respondents was 52.6\%. Present study showed that lack of awareness on blood donation was there even among the health care medical professional students. Hence, a periodic awareness program on blood donation in various educational institutions across India is needed in addition to the medical professional students to achieve a $100 \%$ voluntary blood donation programs. The present study indicates that majority of the participants (61.0\%) never donated blood and observed positive attitude (63.5\%). The reasons for non-donations were no one has ever asked to donate blood; lack of information on blood donation and its importance and don't know where to donate blood and negative attitude (36.4\%) like blood donation makes the person weak, reduce immunity and leads to anemia. ${ }^{8}$ The non-donors with positive attitude should be motivated and awareness about voluntary blood donation should be provided to promote blood donation on voluntary basis, while non-donors with the negative attitude are needed to be educated about the importance and health benefits upon blood donation. Their doubts regarding blood donation should be clarified and they should be motivated to donate blood on regular basis. This study clearly shows that respondents who donated blood once $(22.0 \%)$ are not regular donors because $53.4 \%$ donors said no one has asked them to donate blood again. This indicates that these students are willing to donate blood on regular basis but they need constant awareness about importance of blood donation and regular motivation. ${ }^{9}$ About $34.88 \%$ of donors pointed out that there was no privacy during blood donation, while few (11.6\%) expressed a little discomfort after blood donation. Provision of adequate privacy, awareness, communication materials and advertisements to address the fear factor may strengthen the recruitment and retention of voluntary blood donors to donate blood on regular basis to achieve $100 \%$ of blood donation only on voluntary basis. ${ }^{10}$

\section{Conclusion}

After assessment of 500 individuals we came to the conclusion that awareness and knowledge among students was increased from 28.9 to $52.6 \%$ and after encouraging 500 individual for donation and keeping a target of 100 units collection, we were able to collect 193 units in the course of our project. So, present study concludes that students believe that they are less willing to take part in the VBD due to insufficient information. Hence, a periodic awareness program on voluntary blood donation is needed for even among health care medical students. Students should lead from the front to donate blood regularly on voluntary basis and also to take all necessary steps for spreading awareness about the advantages of blood donation not only for the recipient but also for the donor himself could 
be a motivating factor. Making students aware of recent findings, like frequent and long-term blood donation is associated with a lower risk of cardiovascular events in donors can motivate them to be regular donors. This study will also create awareness on blood donations among the entire medical \& engineering students.

\section{Recommendations}

People are still not aware; they still think thousand times before donating blood and many even do not donate. To bring them out make them aware still many steps waits in future.

- Blood donation drives campaigns should be organized.

- $\quad$ Street plays, movies, awareness drives are necessary for further improvement.

\section{Limitations}

Major limitation of the present study is that only one group of young medical professionals has been considered. Varied groups have to be included then more precise results would have been obtained.

\section{Conflict of Interest: None}

\section{References}

1. Council of Europe. Committee of Ministers. Guide to the preparation, use and quality assurance of blood components: recommendation No. R (95) 15. Manhattan Publishing Company; 1997.

2. Ajzen I. The theory of planned behaviour. Organizational Behaviour and Human Decision Process 1991; 50(2): 179-211.

3. Giles M, McClenahan C, Cairns E et al. An application of the theory of planned behaviour to blood donation: The importance of self-efficacy. Health Educ Res 2004; 19: 380-91.

4. Available from: http://www.searo.who.int/LinkFiles/ BCT_BTS-SEAR.pdf. Last Accessed on 2017 December.

5. Das S, Das S. Blood banks to get quality certificate. 2009. Available from: http://www.financialexpress.com/ news/7-blood-banks-to-get-qualitycertificate/417881/. Last Accessed on 2017 December.

6. World Health Organization. Blood Transfusion Safety. e2008. Available from: http://www.who.int/ bloodsafety/voluntary_donation/en/. Last Accessed on 2017 December.

7. Available from: naco.gov.in/upload/.../29\%20 voluntary\%20blooddonation.pdf. Last Last Accessed on 2017 December.

8. Zaller N, Nelson KE, Ness P et al. Knowledge, attitude and practice survey regarding blood donation in a Northwestern Chinese city. Transfus Med 2005; 15: 277-86.
9. Lemmens KP, Abraham C, Hoekstra T et al. Why don't young people volunteer to give blood? An investigation of the correlates of donation intentions among young donors. Transfusion 2005; 45: 945-55.

10. Hupfer ME, Taylor DW, Letwin JA. Understanding Canadian student motivations and beliefs about giving blood. Transfusion 2005; 45: 149-161.

Date of Submission: 2018-10-01 Date of Acceptance: 2018-10-29 